\title{
Survey of the bryophytes of a gallery forest in the National Park of Serra do Cipó, Minas Gerais, Brazil ${ }^{1}$
}

\author{
Ronaldo Viveiros de Sousa ${ }^{2,3}$ and Paulo Eduardo Aguiar Saraiva Câmara ${ }^{2}$
}

Received: April 29, 2014. Accepted: July 18, 2014

\begin{abstract}
Serra do Cipó has attracted the interest of many researchers over the years because of its unique characteristics, particularly the fact that the site represents the transition between Cerrado and Atlantic Forest. The study area of Serra do Cipó is located along a gallery forest "córrego Três Pontinhas," at $19^{\circ} 16^{\prime} 00^{\prime \prime}$ S and $43^{\circ} 32^{\prime} 49^{\prime \prime}$ W and an altitude of $1,188 \mathrm{~m}$. The objective of this study was to survey the Division Bryophyta in a gallery forest within the National Park of Serra do Cipo, Minas Gerais. Collections were made during the months of November 2009 and July 2011. We found 15 families, 26 genera, 43 species, and 4 varieties of mosses. The families with the largest number of species were Leucobryaceae (10), Sematophyllaceae (9), and Calymperaceae (6). Other families included Fissidentaceae (3), Bryaceae, Pylaisiadelphaceae, Pottiaceae, and Orthotrichaceae (2 spp. each); Brachytheciaceae, Cryphaeaceae, Fabroniaceae, Helicophyllaceae, Hypnaceae, Polytrichaceae, and Sphagnaceae had only 1 sp. each. Three new records for the state of Minas Gerais were found: Acroporium caespitosum, A. longirostre, and Colobodontium vulpinum.
\end{abstract}

Keywords: Acrocarpous, Bryophyta, conservation, mosses, new records, pleurocarpous, taxonomy

\section{Introduction}

With approximately 13,000 described species, the division Bryophyta is the second richest in species among the land plants (Goffinet et al. 2009). In Brazil, there are approximately 883 species (Forzza et al. 2012), but there is still no taxonomic work with a national coverage.

The area of the Serra do Cipó has aroused the interest of researchers over the years due to its unique characteristics, particularly the fact that this region contains the transition between two very important biomes: the Cerrado and Atlantic Forest. The region is also famous for its richness and endemism of rocky grassland (Ribeiro et al. 2009). Further, due to its high importance as a watershed between the basins of the Rio Doce to the east and the San Francisco River to the west, the National Park of Serra do Cipó (PARNA-Cipó) was established by Decree no. 90223 , of September 25, 1984 (Brasil 1984).

PARNA-Cipó is located entirely within the state of Minas Gerais, Brazil, (19 $13^{\prime}$ to $19^{\circ} 32^{\prime}$ S and $43^{\circ} 27^{\prime}$ to $43^{\circ} 27^{\prime}$ W) and covers an area of $31,617.8$ ha with a perimeter of $119,978.5 \mathrm{~m}$, of which 20,764 ha or $65.6 \%$ is in the Jaboticatubas municipality. The other municipalities are Santana do Riacho with 2,615 ha (8.3\%), Morro do Pilar with 5,934 ha $(18.8 \%)$, and Itambé do Mato Dentro with 2,304 ha (7.3\%). The administrative headquarters of PARNA-Cipó are located just $100 \mathrm{~km}$ from the state capital of Minas Gerais, Belo Horizonte (Ribeiro et al. 2009). This city has more than five million inhabitants and is currently the 3rd largest metropolitan area in the country (IBGE 2012). Thus, studies on the biodiversity of this region are urgent as it is known that the city is expanding toward this area, threatening the large number of endemic species of both flora (89 spp.) and fauna as (18 spp.) (Madeira et al. 2008).

Although there is a high a degree of endemism of flowering plants in the Serra do Cipó (Madeira et al. 2008; Santos et al. 2011), nothing is known regarding its bryophyte endemism. The first moss inventories in the Serra do Cipó started with Giulietti et al. (1987), in which 18 species of mosses and 1 liverwort are listed. However, the author fails to mention the habitat of the listed species or the sampling methodology. This number is very low compared to collection reports of other groups of plants in the same locality that may have involved a greater sampling effort, particularly flowering plants (Madeira et al. 2008; Santos et al. 2011). After 24 years, a new, much more comprehensive study on bryophytes was conducted in Serra do Cipó produced by Yano \& Peralta (2011) containing illustrations, identification keys, and descriptions of 142 species of mosses, 93 species of liverworts, and 2 species of hornworts. The present work is part of the project Flora of Serra do Cipó outlined by Giulietti et al. (1987), which has a goal of producing monographs of

\footnotetext{
${ }^{1}$ Part of the dissertation of master degree of the first author available in Portuguese on the link http://hdl.handle.net/10482/16031

${ }^{2}$ Universidade de Brasília - UnB

${ }^{3}$ ronaldoviveirosdesousa@yahoo.com.br
} 
all plant families of the Serra do Cipó. The work of Yano \& Peralta (2011) features a total of 237 species of bryophytes (mosses, liverworts, and hornworts) in the Serra do Cipó against 19 species initially identified, indicating that collection efforts can greatly increase our knowledge of biodiversity in a particular region. This number of 142 species of mosses represents $30 \%$ of the total species within only $0.05 \%$ of area of the State of Minas Gerais (Forzza et al. 2012).

Bryophytes generally thrive best in moist environments (Goffinet et al. 2009), such as gallery forests and forest formations around small rivers (Rezende 1998; MMA 2007). Thus, these environments become prime targets for collection. Indeed, surveys conducted in gallery forests have shown that this environment has a great diversity of bryophytes (Genevro et al. 2006; Câmara 2008a; 2008b; Dias-Neto 2011). Thus, the aim of this study was to conduct a moss survey (Divison Bryophyta) in a gallery forest associated with Três Pontinhas creek, $\left(19^{\circ} 16^{\prime} 00^{\prime \prime} \mathrm{S}\right.$ and $43^{\circ} 32^{\prime} 49^{\prime \prime}$ W), altitude 1,188 meters above sea level located within the National Park of Serra do Cipó. This creek is a tributary of the Indequicé River, which flows into the Parauninha River, a tributary of the Velhas River that is part of the São Francisco River basin, one of the major drainage basins in Brazil.

\section{Material and methods}

Two collecting fieldtrips were undertaken, one day in November 2009 and other day in July 2011.

Sampling followed the methodology of Frahm (2003). Collections were made with the aid of a knife or manually. Species were classified according to the substrate on which they were found with the information obtained from the material examined following Robbins (1952) with modifications: 1) corticolous, on living tree trunk; 2) epiphyllous, on living leaves; 3 ) epixylic, on dead or decaying trunk; 4) rupicolous, on stones and; 5) terrestrial, on the ground.

Identification was performed using keys and literature available and when necessary, by sending the material to specialists. All specimens are stored at the Herbarium of the University of Brasília (UB).

Taxa are presented in Table 1 in alphabetical order of family, genus, and species following the classification system proposed by Goffinet et al. (2009). The concept of acrocarpous, cladocarpous, and pleurocarpous follows La Farge-England (1996) and is applied to mosses of Superclass $\mathrm{V}$ (Goffinet et al. 2009). The information regarding the geographical distribution and biogeographical domains were taken from Costa et al. (2011) and Forzza et al. (2012).

\section{Results and discussion}

A total of 176 herbarium specimens were examined: 120 were collected while 56 were already archived in the herbarium UB.
A total of 43 species were found (Tab. 1), representing about $30 \%$ of the number of species of mosses studied by Yano \& Peralta (2011). In addition, three new species were recorded for the state of Minas Gerais and 12 more species were identified that have not been cited by Yano \& Peralta (2011), but while the latter listed the moss flora of the Serra do Cipó, this paper lists the mosses collected in just one single gallery forest located within the PARNA-Cipó.

The species studied were collected in four different substrates with corticolous accounting for $49 \%$ and terrestrial substrate accounting for $30 \%$. This result was expected, since the corticolous substrate is widely available in an area of forest vegetation (Santos \& Costa 2008).

\section{Mosses and gallery forests}

Studies focusing solely on bryophytes in gallery forests of the Cerrado are rare, the first being Genevro et al. (2006) that lists 33 species in a gallery forest in a park in Mato Grosso state, Câmara (2008a, 2008b) with 41 species in the gallery forest of a nature reserve in the Federal District and the as yet unpublished dissertation of Dias-Neto (2011) listing 53 species within a protected area also in the Federal District. With the exception of the work done by Genevro et al. (2006) that was based on a collection in a single gallery forest, others were based on collecting in multiple gallery forests and, although the work presented here has also been made based on a double collection in the same gallery forest, the number of species identified was higher than those collected by Câmara (2008a, 2008b) in multiple gallery forests in a given locality. This value of 43 species indicates a high diversity of mosses in this region as the collection was made in a single gallery forest, and still managed to cover about $4.9 \%$ of total species, $10 \%$ of the genera, and $21 \%$ of families of mosses occurring in Brazil.

The most common species collected was Sematophyllum subpinnatum with 38 samples, more than double the second most collected which was Schlotheimia rugifolia with 15 samples. Genevro et al. (2006) found that these species are represented by one or two samples. Câmara (2008a, 2008b) also collected more S. subpinnatum with 16 samples, but the second most collected was Octoblepharum albidum with 15 samples. In the study by Dias-Neto (2011), it was not possible to determine which was the most collected species because he describes species collected in his dissertation only as pleurocarpous mosses.

When compared with published data for the Atlantic Forest, Oliveira et al. (2002) found the most abundant species were S. subpinnatum, Vesicularia vesicularis, and Isopterygium tenerifolium. In the study by Siqueira et al. (2011), the most abundant species were S. subpinnatum, Orthostichopsis praetermissa, and Henicodium geniculatum. In the other works consulted (Costa \& Silva 2003; Visnadi 2005; Santos \& Costa 2008; Valente et al. 2009), it was not possible to ascertain the most collected species. 
Table 1: Species of mosses occurring in the gallery forest stream Três Pontinhas, National Park of Serra do Cipó, MG, Brazil, with data on geographical distribution and substrate. Substrates (Sub.): $\mathrm{CO}=$ corticolous, $\mathrm{EX}=$ epixylic, $\mathrm{EF}=$ epiphyllous, $\mathrm{RU}=$ rupicolous, $\mathrm{TE}=$ terrestrial. Phytogeographic domains $(\mathrm{Phyt}$. dom.): Amazon Rainforest $=$ AM, Atlantic Rainforest $=$ AT, Central Brazilian Savanna $=$ SA, Caatinga $=$ CA, Pampa $=$ PA, Pantanal $=$ PL. In parentheses next to each family represents the number of genera and species. ${ }^{*}$ new record for the state of Minas Gerais, ${ }^{* *}$ new occurrence for the National Park of Serra do Cipó.

\begin{tabular}{|c|c|c|c|c|}
\hline Species & Sub. & Phyt. dom. & World distr. & Vouchers \\
\hline \multicolumn{5}{|l|}{ ACROCARPOUS } \\
\hline \multicolumn{5}{|l|}{ BRYACEAE Schwägr. (2/2) } \\
\hline Bryum caespiticium Hedw. ${ }^{* *}$ & $\mathrm{RU}$ & AT & Cosmopolitan & Sousa, R.V.178, 188 \\
\hline $\begin{array}{l}\text { Rosulabryum billarderi (Schwägr.) J.R. } \\
\text { Spence }\end{array}$ & $\mathrm{TE}$ & AM, AT, PA, PL, SA & Cosmopolitan & Sousa, R.V. 201 \\
\hline \multicolumn{5}{|l|}{ CALYMPERACEAE Kindb. (2/6) } \\
\hline Octoblepharum albidum Hedw. & $\mathrm{CO}$ & AM, AT, CA, PA, PL, SA & Pantropical & Câmara, P.E.A.S. 2118-a \\
\hline Syrrhopodon gaudichaudii Mont. & $\mathrm{CO}$ & AM, AT, CA, PL, SA & Pantropical & Câmara, P.E.A.S. 2102 \\
\hline $\begin{array}{l}\text { Syrrhopodon lycopodioides (Sw. ex Brid.) } \\
\text { Müll. Hal. ** }\end{array}$ & RU & AT & Neotropical & Câmara, P.E.A.S. 2085 \\
\hline Syrrhopodon parasiticus (Sw. ex Brid.) Paris & $\mathrm{CO}, \mathrm{EX}$ & AM, AT, PL, SA & Pantropical & $\begin{array}{l}\text { Duarte-Silva, A.G. 72, Gonzaga, R.M.O. 93; } \\
\text { Sousa, R.V. 150, } 168\end{array}$ \\
\hline Syrrhopodon prolifer Schwägr. var. prolifer & CO, RU, TE & AM, AT, CA, AS & Pantropical & $\begin{array}{l}\text { Duarte-Silva, A.G. 77; Câmara, P.E.A.S. 2141, } \\
\text { 2149; Sousa, R.V. 155, 156, 165, 171, } 275\end{array}$ \\
\hline Syrrhopodon tortilis Hampe & $\mathrm{CO}$ & AT & Neotropical & Câmara, P.E.A.S. 2096 \\
\hline \multicolumn{5}{|l|}{ FISSIDENTACEAE Schimp. (1/3) } \\
\hline Fissidens lagenarius Mitt. var. lagenarius ${ }^{* *}$ & $\mathrm{CO}$ & AT, CA, PL, SA & Neotropical & Sousa, R.V. 191 \\
\hline Fissidens pellucidus Hornsch. var. pellucidus ${ }^{* *}$ & EX & AM, AT, CA, PA, PL, SA & Neotropical & Duarte-Silva, A.G. 71 \\
\hline Fissidens serratus Müll. Hal. ${ }^{* *}$ & $\mathrm{TE}$ & $\mathrm{AM}, \mathrm{AT}, \mathrm{CA}, \mathrm{AS}$ & Neotropical & Sousa, R.V. 280 \\
\hline \multicolumn{5}{|l|}{ LEUCOBRYACEAE Schimp. (3/10) } \\
\hline Campylopus dichrostris (Müll. Hal.) Paris & $\mathrm{CO}, \mathrm{EX}$ & AT, SA & Endemic of Brazil & Sousa, R.V. 198, 266, 279 \\
\hline Campylopus occultus Mitt. & $\mathrm{CO}$ & AM, AT, PA, PL, SA & Neotropical & Sousa, R.V. 162 \\
\hline Campylopus pilifer Brid. & RU & $\mathrm{AM}, \mathrm{AT}, \mathrm{CA}, \mathrm{PA}, \mathrm{SA}$ & Neotropical & Câmara, P.E.A.S. 2155; Sousa, R.V. 148, 169 \\
\hline Campylopus richardii Brid. & RU & AM, AT & Neotropical & Câmara, P.E.A.S. 2155 \\
\hline Campylopus savannarum (Müll. Hal.) Mitt. & $\mathrm{CO}$ & AM, AT, CA, PL, SA & Pantropical & Câmara, P.E.A.S. 2034-b; Sousa, R.V. 189 \\
\hline Campylopus thwaitesii (Mitt.) A. Jaeger & $\mathrm{CO}, \mathrm{EX}$ & AT & Endemic of Brazil & $\begin{array}{l}\text { Câmara, P.E.A.S. 2036-a, 2070; Sousa, R.V. } \\
193\end{array}$ \\
\hline Leucobryum clavatum Hampe & $\mathrm{TE}$ & AT, SA & Endemic of Brazil & Sousa, R.V. 176 \\
\hline Leucobryum crispum Müll. Hal. & $\mathrm{TE}$ & AM, AT, SA & Neotropical & $\begin{array}{l}\text { Câmara, P.E.A.S. 2045, 2056; Duarte-Silva, } \\
\text { A.G. } 88 \text {; Gonzaga, R.M.O. 112, 118; Sousa, } \\
\text { R.V. } 194,203,268\end{array}$ \\
\hline $\begin{array}{l}\text { Leucobryum martianum (Hornsch.) } \\
\text { Hampe ex Müll. Hal. }\end{array}$ & RU, TE & AM, AT, CA, PL, SA & Neotropical & $\begin{array}{l}\text { Duarte-Silva, A.G. 88; Câmara, P.E.A.S. 2062, } \\
\text { 2083, 2113, 2114, 2125, 2131, 2132, } 2149\end{array}$ \\
\hline Ochrobryum gardneri (Müll. Hal.) Mitt. & EX & $\mathrm{AM}, \mathrm{AT}, \mathrm{PL}, \mathrm{SA}$ & $\begin{array}{l}\text { Neotropical and } \\
\text { Africa }\end{array}$ & Câmara, P.E.A.S. 2099-b \\
\hline \multicolumn{5}{|l|}{ POLYTRICHACEAE Schwägr. (1/1) } \\
\hline Polytrichum commune Hedw. & $\mathrm{TE}$ & AM, AT, SA & Cosmopolitan & Sousa, R.V. 267 \\
\hline \multicolumn{5}{|l|}{ POTTIACEAE Schimp. (2/2) } \\
\hline Barbula indica (Hook.) Spreng. & $\mathrm{TE}$ & AM, AT, CA, PL, SA & Pantropical & Câmara, P.E.A.S. 2115 \\
\hline $\begin{array}{l}\text { Hymenostylium recurvirostrum (Hedw.) } \\
\text { Dixon }{ }^{* *}\end{array}$ & RU & AT, SA & Cosmopolitan & Câmara, P.E.A.S. 2145 \\
\hline
\end{tabular}

\section{CLADOCARPOUS}

HELICOPHYLLACEAE Broth. (1/1) 


\begin{tabular}{|c|c|c|c|c|}
\hline Species & Sub. & Phyt. dom. & World distr. & Vouchers \\
\hline \multicolumn{5}{|l|}{ ORTHOTRICHACEAE Arn. (2/2) } \\
\hline Macromitrium richardii Schwägr. & $\mathrm{CO}, \mathrm{EX}$ & AM, AT & Neotropical & Gonzaga, R.M.O. 87, 121 \\
\hline Schlotheimia rugifolia (Hook.) Schwägr. & $\mathrm{CO}$ & AM, AT, SA & $\begin{array}{l}\text { Neotropical and } \\
\text { India }\end{array}$ & $\begin{array}{l}\text { Câmara, P.E.A.S. 2027, 2111; Duarte-Silva, } \\
\text { A.G. } 73,75,91 \text {; Sousa, R.V. 152, 153, 167, 170, } \\
\text { 174, 199, 256, 274, 279, } 280\end{array}$ \\
\hline \multicolumn{5}{|l|}{ PLEUROCARPOUS } \\
\hline \multicolumn{5}{|l|}{ BRACHYTHECIACEAE Schimp. (1/1) } \\
\hline Squamidium brasiliense (Hornsch.) Broth. & EX & AT & $\begin{array}{l}\text { Africa and } \\
\text { Americas }\end{array}$ & Sousa, R.V. 260 \\
\hline \multicolumn{5}{|l|}{ CRYPHAEACEAE Schimp. (1/1) } \\
\hline $\begin{array}{l}\text { Schoenobryum concavifolium (Griff.) } \\
\text { Gangulee }{ }^{*}\end{array}$ & $\mathrm{CO}, \mathrm{EX}$ & AM, AT, PA, PL, SA & Cosmopolitan & Sousa, R.V. 197, 200 \\
\hline \multicolumn{5}{|l|}{ FABRONIACEAE Schimp. (1/1) } \\
\hline Fabronia ciliaris (Brid.) Brid. var. ciliaris & $\mathrm{TE}$ & AT, CA, SA & $\begin{array}{l}\text { Bolívia, Chile, } \\
\text { Ecuador and } \\
\text { EUA }\end{array}$ & Sousa, R.V. 271 \\
\hline \multicolumn{5}{|l|}{ HYPNACEAE Schimp. (1/1) } \\
\hline $\begin{array}{l}\text { Chryso-hypnum diminutivum (Hampe) } \\
\text { W.R. Buck }\end{array}$ & EX & AM, AT, PA, PL, SA & Cosmopolitan & Câmara, P.E.A.S. 2148 \\
\hline \multicolumn{5}{|l|}{$\begin{array}{l}\text { PYLAISIADELPHACEAE Goffinet \& W.R. } \\
\text { Buck (2/2) }\end{array}$} \\
\hline Isopterygium tenerum (Sw.) Mitt. & $\mathrm{CO}, \mathrm{EX}, \mathrm{TE}$ & AM, AT, CA, PA, PL, SA & Cosmopolitan & $\begin{array}{l}\text { Câmara, P.E.A.S. 2034-b; Gonzaga, R.M.O. } \\
\text { 100; Sousa, R.V. } 156\end{array}$ \\
\hline Wijkia flagellifera (Broth.) H.A. Crum & $\mathrm{CO}$ & AT & Neotropical & $\begin{array}{l}\text { Duarte-Silva, A.G. 75; Gonzaga, R.M.O. 94; } \\
\text { Sousa, R.V. 276, } 277\end{array}$ \\
\hline \multicolumn{5}{|l|}{ SEMATOPHYLLACEAE Broth. (5/9) } \\
\hline $\begin{array}{l}\text { Acroporium caespitosum (Hedw.) W.R. } \\
\text { Buck }^{*}\end{array}$ & $\mathrm{TE}$ & AT, SA & Neotropical & Câmara, P.E.A.S. 2112 \\
\hline Acroporium longirostre (Brid.) W.R. Buck * & $\mathrm{CO}, \mathrm{RU}$ & AM, AT, SA & Neotropical & Câmara, P.E.A.S. 2087, 2107 \\
\hline Aptychopsis subpungifolia (Broth.) Broth. ** & $\mathrm{CO}$ & AT & Endemic of Brazil & $\begin{array}{l}\text { Duarte-Silva, A.G. } 87 \text {; Gonzaga, R.M.O. 91,95; } \\
\text { Sousa, R.V. 160,270 }\end{array}$ \\
\hline $\begin{array}{l}\text { Colobodontium vulpinum (Mont.) S.P. } \\
\text { Churchill \& W.R. Buck* }\end{array}$ & RU & AM, AT, SA & Neotropical & $\begin{array}{l}\text { Câmara, P.E.A.S. 2110; Duarte-Silva, A.G. } \\
83,86\end{array}$ \\
\hline $\begin{array}{l}\text { Donnellia commutata (Müll. Hal.) W.R. } \\
\text { Buck }\end{array}$ & $\mathrm{CO}, \mathrm{EX}$ & AM, AT, PL, SA & Neotropical & $\begin{array}{l}\text { Câmara, P.E.A.S. 2028, 2041, 2075-a, 2069, } \\
\text { 2105, 2129; Gonzaga, R.M.O. 120; Sousa, } \\
\text { R.V.146, 154, 157, 180, 192, 273, } 278\end{array}$ \\
\hline $\begin{array}{l}\text { Sematophyllum adnatum (Michx.) E. } \\
\text { Britton }\end{array}$ & EX, RU & $\mathrm{AM}, \mathrm{AT}, \mathrm{CA}, \mathrm{AS}$ & $\begin{array}{l}\text { America tropical } \\
\text { and subtropical } \\
\text { and tropical } \\
\text { Africa }\end{array}$ & Câmara, P.E.A.S. 2037-a, 2140 \\
\hline Sematophyllum galipense (Müll. Hal.) Mitt. & EX, RU & AM, AT, SA & Neotropical & $\begin{array}{l}\text { Câmara, P.E.A.S. 2049, 2051-b, 2086, 2095-a, } \\
\text { 2103-a; Gonzaga, R.M.O. 120; Sousa, R.V. } 183\end{array}$ \\
\hline $\begin{array}{l}\text { Sematophyllum subpinnatum (Brid.) E. } \\
\text { Britton }\end{array}$ & $\mathrm{CO}, \mathrm{EX}, \mathrm{RU}$ & AM, AT, CA, PA, PL, SA & Pantropical & $\begin{array}{l}\text { Câmara, P.E.A.S. 2040, 2066, 2067, 2104, } \\
\text { 2128-a; Duarte-Silva, A.G. 73, 76, 85, 93, 71, } \\
\text { 67, 92, G. 86, 90, 101, 104, 106, 107, 108, 109, } \\
\text { 115, 119; Sousa, R.V. 145, 151, 154-a, 161, 173, } \\
\text { 177, 185, 186, 187, 159, 168, 184, 195, 197, } \\
\text { 198, } 278\end{array}$ \\
\hline Sematophyllum subsimplex (Hedw.) Mitt. & $\begin{array}{l}\text { CO, EX, } \\
\text { RU, TE }\end{array}$ & AM, AT, CA, PL, SA & Neotropical & $\begin{array}{l}\text { Câmara, P.E.A.S. 2038-a, 2116; Duarte-Silva, } \\
\text { A.G. } 69,82,80,89 \text {; Gonzaga, R.M.O. 87, 120; } \\
\text { Sousa, R.V. 156, 179, 196, } 273\end{array}$ \\
\hline \multicolumn{5}{|l|}{ WITHOUT CLASSIFICATION } \\
\hline \multicolumn{5}{|l|}{ SPHAGNACEAE Dumort. (1/1) } \\
\hline Sphagnum submedium Warnst. ** & $\mathrm{TE}$ & AT & Endemic of Brazil & Sousa, R.V. 201 \\
\hline
\end{tabular}


It can be concluded that Sematophyllum subpinnatum is the most collected among mosses during collecting expeditions, whether in gallery forests of the Cerrado biome, or in the Atlantic Forest.

\section{Distribution of acrocarpous and pleurocarpous mosses}

Acrocarpous mosses were found more abundantly in open and exposed areas and are known to be more resistant to dehydration than pleurocarpous mosses (Goffinet $e t$ al. 2009; Govindapyari et al. 2012), and as the collection took place in a gallery forest, is was expected that there would be a predominance of pleurocarpous mosses over the acrocarpous mosses, but our data showed otherwise. The acrocarpous mosses represented $53 \%$ of the species found. Câmara (2008a; 2008b) also demonstrated the occurrence of more pleurocarpous than acrocarpous mosses (54\%), well as Dias-Neto (2011) with $42 \%$, both in the Federal District, Brazil. Genevro et al. (2006) is the only reference that shows the occurrence of more pleurocarpous mosses (53\%).

When examining the distribution of acro and pleurocarpous mosses in the Atlantic Forest, the data show a balance, with three studies (Oliveira et al. 2002; Costa \& Silva 2003; Siqueira et al. 2011) showing the occurrence of more acrocarpous than pleurocarpous mosses, and three studies (Visnadi 2005; Santos \& Costa 2008; Valente et al. 2009) showing the opposite. Note that we used only those studies in which there was a complete list of mosses and families, and those wrongly applied in a category were corrected using the criteria proposed by La Farge-England (1996) and Goffinet et al. (2009). Such information becomes more relevant when one takes into consideration that the pleurocarpous mosses form one of the most diverse groups within the Division Bryophyta, with approximately $45 \%$ of the genera (Cox et al. 2010) and its most common habitat is on trunks and leaves of angiosperms (Shaw et al. 2003). It is exactly this type of environment that is common in a gallery forest in the Cerrado biome (Rezende 1998; MMA 2007) and the Atlantic Forest is characterized by a moist environment and the formation of a dense arboreal canopy (Rambaldi et al. 2003).

\section{Substratum preference and geographical distribution}

From our data, it can be noted that the substrate corticolous was predominant in all mosses, either acro, pleuro, or cladocarpous, but the rupicolous and terrestrial substrates were not observed in cladocarpous mosses. The epiphyllous substrate was not observed in any mosses.

As for the distribution by phytogeographic domains, eight species (19\% of the total) are so far considered ex- clusive to the Atlantic. They are Aptychopsis subpungifolia, Bryum caespiticium, Campylopus thwaitesii, Sphagnum submedium, Squamidium brasiliense, Syrrhopodon lycopodioides, S. tortilis, and Wijkia flagellifera. No other phytogeographic domain shows exclusive species. All 43 species occur in the Atlantic Forest and 32 of 43 species occur in the Cerrado.

By observing this distribution, it can be inferred that in principle, the moss flora of the gallery forest creek Três Pontinhas, is represented to a greater degree by mosses from the Atlantic Forest than to the Cerrado. However, this can only be concluded after an ecological study to test this hypothesis.

\section{Conservation status}

Regarding the conservation status of the species studied, none of the presented species (nor any other in the region), occur in MMA Instruction No. 06 of 2008 (MMA 2008), the official list of endangered species used by the Brazilian government. In addition, the Red List of the International Union for Conservation of Nature and Natural Resources (IUCN) mentions 44 species of mosses with some degree of endangerment, and none are found the National Park of Serra do Cipó.

The moss species identified in this study have a widespread occurrence in Brazil. The only species occurring here that could possibly become more vulnerable would be because they occur in only three of the twenty-seven states of Brazil and the Federal District and are endemic to the country. These are A. subpungifolia and S. submedium. A. subpungifolia was identified with the help of photographs of the type specimen, as this species can be confused with other species of the genre Acroporium because both have elongated leaves and inclined alar cells at an angle of ca. $45^{\circ}$. However, A. subpungifolia has as distinctive features the straight margin and alar cells with thickened walls. As for S. submedium according to Crum (1992), this species is close to Sphagnum buckianum, but differs in having larger pores evenly distributed in cells and, unlike $S$. buckianum in which the pores have restricted ends, S. submedium presents three groups of fascicles with one pending, while S. buckianum presents two, both scattered.

Far from indicating that bryophytes are in a safe situation, the work of Câmara \& Carvalho-Silva (2011) demonstrates the gaps existing in the study of bryophytes and that the realization that even apparently common species are endangered can occur when further studies are conducted.

The data discussed in this work along with other literature demonstrates that the National Park of Serra do Cipó has a very diverse flora of bryophytes, in view that an area of a few tens of meters along a gallery forest was sampled, but also demonstrates that more comprehensive studies on the ecology of the species are necessary. 


\section{Acknowledgments}

The authors acknowledge the generous help of Dr. Denilson F. Peralta and his team in identifying specimens and pleasant moments in the Botanical Institute of São Paulo and colleagues of the laboratory of cryptogams at UnB. The first author also thanks CAPES/REUNI for the scholarship provided and Dra. Micheline Carvalho Silva and Dra. Dulce Maria da Rocha Sucena for invaluable advice and discussions about this work and Dr. Christopher W. Fagg for reviewing the English text.

\section{References}

Brasil. Presidência da República. Decreto n 90.223, de 25 de Setembro de 1984. Cria, no Estado de Minas Gerais, o Parque Nacional da Serra do Cipó e dá outras providências. Diário Oficial da União Seção 1. 26/09/1984. p. 14013.

Câmara PEAS. 2008a. Musgos Pleurocárpicos das matas de galeria da Reserva Ecológica do IBGE, RECOR, Distrito Federal, Brasil. Acta Botanica Brasilica 22: 573-581.

Câmara PEAS. 2008b. Musgos Acrocárpicos das matas de galeria da Reserva Ecológica do IBGE, RECOR, Distrito Federal, Brasil. Acta Botanica Brasilica 22: 1027-1035.

Câmara PEAS, Carvalho-Silva M. 2011. Taxithelium juruense (Broth.) Broth. (Pylaisiadelphaceae) na endangered Brazilian endemic, with notes on the genus Taxithelium for Brazil. Acta Botanica Brasilica 25: 198-202.Costa DP, Silva AG. 2003. Briófitas da Reserva Natural do Rio Doce, Linhares, Espírito Santo, Brasil. Boletim do Museu de Biologia Mello Leitão, Nova Série 16: 21-38.

Costa DP, Pôrto KC, Luizi-Ponzo AP, et al. 2011. Synopsis of the Brazilian moss flora: checklist, synonyms, distribution and conservation. Nova Hedwigia 93: 277-334.

Cox CJ, Goffinet B, Wickett NJ, Boles SB, Shaw J. 2010. Moss diversity: A molecular phylogenetic analysis of genera. Phytotaxa 9: 175-195.

Crum H. 1992. Miscellaneous Notes on the Genus Sphagnum. 3. New Species From Brazil. The Bryologist 95: 419-429.

Dias-Neto RG. 2011. Briófitas de Matas de Galerias da APA de Cafuringa, Brasília, DF-Brasil. Msc Thesis. Universidade de Brasília, Brazil.

Forzza RC, Leitman PM, Costa AF, et al. 2010. Lista de Espécies da Flora do Brasil. Jardim Botânico do Rio de Janeiro. http://floradobrasil.jbrj. gov.br/2012. 04 Aug. 2012.

Frahm JP. 2003. Manual of Tropical Bryology: Morphological adaptations. Tropical Bryology 23: 29-38.

Genevro JA, Athayde Filho FP, Peralta DF. 2006. Briófitas de mata de galeria no Parque Municipal Mário Viana, Nova Xavantina, Mato Grosso, Brasil. Boletim do Instituto de Botânica 18: 149-157.

Giulietti AM, Menezes NL, Pirani JR, Meguro M, Wanderley MGL. 1987. Flora da Serra do Cipó, Minas Gerais: Caracterização e lista de espécies. Boletim de Botânica da Universidade de São Paulo 9: 1-151.

Goffinet B, Buck WR, Shaw AJ. 2009. Morphology, anatomy, and classification of the Bryophyta. In: Goffinet B, Shaw AJ. (eds.) Bryophyte Biology. 2nd edn. Cambridge, Cambridge University Press. p. 55-138.
Govindapyari H, Kumari P, Bahuguna YM, Uniyal PL. 2012. Evaluation of species richness of acrocarpous mosses in Imphal District, Manipur, India. Taiwania 57: 14-26.

IBGE - Instituto Brasileiro de Geografia e Estatística. 2012. Estimativas populacionais para os municípios brasileiros em 01.07.2012. http:// www.ibge.gov.br/home/estatistica/populacao/estimativa2012/default. shtm. 07 Mar. 2013

La Farge-England C. 1996. Growth form, branching pattern, and perichaetial position in mosses: cladocarpy and pleurocarpy redefined. The Bryologist 99: 170-186.

Madeira JA, Ribeiro KT, Oliveira MJR, Nascimento JS, Paiva CL. 2008. Distribuição espacial do esforço de pesquisa biológica na Serra do Cipó, Minas Gerais subsídios ao manejo das unidades de conservação da região. Megadiversidade 4: 257-271.

MMA - Ministério do Meio Ambiente. 2007. Biodiversidade do cerrado e pantanal: áreas e ações prioritárias para conservação da biodiversidade. Brasília: MMA/SBF. Série Biodiversidade 17. 1-540.

MMA - Ministério do Meio Ambiente. 2008. Instrução normativa n 06, de 26 de setembro de 2008 .

Oliveira-e-Silva MIMN, Milanez AI, Yano O. 2002. Aspectos ecológicos de briófitas em áreas preservadas de Mata Atlântica, Rio de Janeiro, Brasil. Tropical Bryology 22: 77-102.

Rambaldi DM, Magnani A, Ilha A, Lardosa E, Figueiredo P, Oliveira RF. 2003. A Reserva da Biosfera da Mata Atlântica no Estado do Rio de Janeiro. Série Estados e Regiões da RBMA. Caderno da Reserva da Biosfera da Mata Atlântica. Rio de Janeiro, CNRBMA.

Rezende AV. 1998. Importância das matas de galeria: manutenção e recuperação. In: Ribeiro. (ed.) Cerrado, matas de galeria. Planaltina, EMBRAPA-CPAC.

Ribeiro KT, Nascimento JS, Madeira JA, Ribeiro LC. 2009. Aferição dos limites da Mata Atlântica na Serra do Cipó, MG, Brasil, visando maior compreensão e proteção de um mosaico vegetacional fortemente ameaçado. Natureza e Conservação 7: 30-49.

Robbins RG. 1952. Bryophyte Ecology of a Dune Area in New Zealand. Vegetatio 4: 1-31.

Santos ND, Costa DP. 2008. A importância de Reservas Particulares do Patrimônio Natural para a conservação da brioflora da Mata Atlântica: um estudo em El Nagual, Magé, RJ, Brasil. Acta Botanica Brasilica 22: 359-372.

Santos MF, Serafim H, Sano PT. 2011. Fisionomia e composição da vegetação florestal na Serra do Cipó, MG, Brasil. Acta Botanica Brasilica 25: 793-814

Shaw AJ, Cox CJ, Goffinet B, Buck WR, Boles SB. 2003. Phylogenetic evidence of a rapid radiation of pleurocarpous mosses (Bryophyta). Evolution 57: 2226-2241.

Siqueira SMC, Costa PS, Souza EB, Oliveira HC. 2011. Briófitas de um remanescente de Mata Atlântica no Município de Ubajara, CE, Brasil. Hoehnea 38: 597-608.

Valente EB, Pôrto KC, Boas-Bastos SBV, Bastos CJB. 2009. Musgos (Bryophyta) de um fragmento de Mata Atlântica na Serra da Jibóia, município de Santa Terezinha, BA, Brasil. Acta Botanica Brasilica 23:369-375.

Visnadi SR. 2005. Brioflora da Mata Atlântica do Estado de São Paulo: região norte. Hoehnea 32: 215-131.

Yano O, Peralta DF. 2011. Flora da Serra do Cipó, Minas Gerais: Briófitas (Anthocerotophyta, Bryophyta e Marchantiophyta). Boletim de Botânica da Universidade de São Paulo 29: 135-299. 